\title{
下肢長不同に対する手術的治療の経験
}

島 根 整 肢 学 園

花 北良臣山根実

浜 崎 条男

\section{Surgical Treatment of Ineguality of the Lower Limbs}

By

\section{Y. Hanakita, M. Yamane and K. Hamasaki \\ Shimane Crippled Children' Hospital}

一侧下肢の僅かな短縮は脊柱の側彎によつて代償さ れるが, 高度の短縮は従来各種の装具によつて補椮さ れるのが常である.しかし最近では下肢延長術を主と する積極的な治療の報告が見られるので，乙の㙨会に 我々の下肢長差矯正手術の経験を報告し, 下肢延長術 の適応，効果等について吟味したいと思う。

\section{症例 (表)}

第 1 例. 14才．男. 左先天性下腿偽関節による下肢 の短縮があり，偽関節部の中，脛骨は Boyd の dual graft により，腓骨は晹骨片を串刺しに移植した絬 果，何れも骨性に癒合したが，なほ患肢にX線計測上 $16.0 \mathrm{~cm}$ の短縮があり杖なしには歩行出来ない. 先づ 健側大腿骨中央部に於て骨幹部を全層 $3 \mathrm{~cm}$ 除去して キュンチャ一釘で固定，患侧は線状骨切り術后，綱線 搽引を行いその結果生じた間隙に健側より採取した骨 片を串刺しに移植しキュンチャ一釷で固定した。脚長 差はなほも $10.5 \mathrm{~cm}$ を残してるるが，靴型装具の着用 によつて松葉杖を用うることなく患肢を接地して歩行 が可能となつた，然し大腿に於ける延長は鋼線牽引で は $3 \mathrm{~cm}$ の延長さえも困難でその上，延長側の骨癒合
は不良で再手術（骨移植）を要したこと，膌関節拘縮 (们動簋囲 130 度〜180 度) を残したとと等よりして, 結果的には特殊な大腿骨延長器を使用するか, それと 屯下腿延長術乃至切断, 義肢装着の適応ではなかつた 功考えている.

第 2 例. 13才. 女子. クリッペル，ウェーバー氏病 による右下肢把大に対する手術である．X線計测によ る初聄時の脚長差は $4.7 \mathrm{~cm}$ (大腿長差 $0.7 \mathrm{~cm}$ 十下腿長 差 $4.0 \mathrm{~cm}$ ) で，朌長差の大半は下腿長差であるところ から，第 1 回于術として，患侧脛骨近位骨端線を破壊 した後X線コントロール下に 4 本のステープルを打込 む. (stapling). 術后 8 ケ月のX線計測の結果, 全脚 長差は却つて增大したが, 下腿長差は不変であつたか ら, stapling 屯多少は効果があつたと考えられる。な ほあ脚長差は $5.9 \mathrm{~cm}$ むあるため, staple は残したま ま患侧大腿骨中央部に於て $3 \mathrm{~cm}$ の短縮骨切り術を行 つた結果, 脚長差は $1.2 \mathrm{~cm}$ に減じ, 脊柱側彎は消失 し殆んど跛行を浔めなくなつた。

第 3 例. 9 才. 男. 右先天性下腿偽関節. 切診時下 腿に前方凸の屈曲があるため下肢長差は $12 \mathrm{~cm}$ で而む

下肢長不同に対する手術的治療

\begin{tabular}{|c|c|c|c|c|c|c|c|c|}
\hline 症 例 & 性 & 年令 & 因 & 疾 & 治 & 療 & & 法 \\
\hline 第 1 例 & $\hat{\jmath}$ & 14 & \multicolumn{2}{|c|}{ 先天性下腿偽関節 } & $\begin{array}{l}\text { 患側：大腿骨 } \\
\text { 硉側 : 大腿骨 }\end{array}$ & $\begin{array}{l}\text { 延長 } \\
\text { 短縮 }\end{array}$ & & \\
\hline 第 2 例 & 우 & 14 & \multicolumn{2}{|c|}{ クリッペル・ウェーバー氏病 } & 患側：脛骨 & ステープリング & 大腿骨 & 短縮 \\
\hline 第 3 例 & $\hat{\jmath}$ & 9 & \multicolumn{2}{|c|}{ 先天性下腿偽関節 } & 患側：脛骨 & 延長 骨接合術 & & \\
\hline 第 4 例 & $\hat{\jmath}$ & 13 & ポ & & 患側：脛骨 & 延長 & & \\
\hline 第 5 例 & 우 & 12 & 下腿骨髄 & & " & & & \\
\hline
\end{tabular}


その殆んどは下腿長の差である，先づ偽関節部を切離 した後, 片山一平川氏下腿延長器を用ひて屈旧転位を 矯止し, 約 1 ケ月間に $3.5 \mathrm{~cm}$ 延長した. 引綒いて延 長器を除去し，健侧脛骨より採取した舦年を倾つて Dual Graft (Boyd) を行つたが，その後移植䅉の中

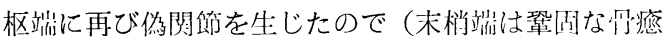
合を示す)，再移植術を行い経過微察中である.

第 4 例. 13 才. 男. ポ少才に上る有侧 $8.0 \mathrm{~cm}$ の等 縮がある，患倒股および膝関節は筋力娍弱する屯，自 動可政性があり下肢の挙上運動も可能であるが，足関 節は動摇関節を呈し，あしゆびの底属が辛うじて可能 な状態で, 延長術後起り得る合併症を予想した場合, 下腿延長術に最適の症例之判断, 片山式延長器を使用 して下腿延長術を行つた。下腿骨中先づ腓骨は骨鋸に て斜比切り, 脛骨は前额而に於て $Z$ 字状に切り, 術直 後に $0.5 \mathrm{~cm}$ 延長. その後は每日 $0.1 \mathrm{~cm}$ (午前, 午後 の定時に $0.05 \mathrm{~cm}$ 宛）宛延長し, 計 $4.6 \mathrm{~cm}$ の延長を 行つた. 術後の初期に腓骨神経麻㾇症状（運艕神経は ポリオのためにすでに麻㾝しているので, 疼痛と知覚 異常である）を示したが，乙れは数日間延長を停止す るととによつて消失し, 以後の延長操作に何等差支え なく，骨瘏合も骨移植を行うことなく完成した。また 延長の結果高度の尖足を来したのでアキレス腱延長 術, 後方関節制動術を施行した. 現在歩行練習中であ るが，脚長差は短縮されたにむ拘らず，歩容の改善は 期待した程には得られず，目下靴型装具の製作中であ る.

第 5 例. 12 才. 女. 右下腿骨打よび踵骨骨髅炎に基 く下肢短縮で, $X$ 線計測上 $7.5 \mathrm{~cm}$ の短縮を呈する. 第 4 例之同様の方法で $5 \mathrm{~cm}$ の延長を行い, 現在延長 器装着のまま骨療合完成を待機中である.

$$
\text { 考按 }
$$

脚長差矯正の手段として最近下肢延長術という稆極
的于段が流行し，木年の総会でも活潑な討諭が行われ たが，乙れ等の㳔諭の殆んどは下肢延長術の部位，手 術丁:挍抢よび合併症という椂などちらかといえば枝葉 末節に属することで，呢も重要な末手術の適応とか効 果についてはふれていなかつたように思う。脚長差が ある場合，その差を縮め更にはなくすることが出来れ ば，手術としての下肢延長術は成功であろうが，その 絬果予定した下肢の延長が命併症むなく完企な骨痖合 のもとに得られたとしても，終局の目慓である歩容の

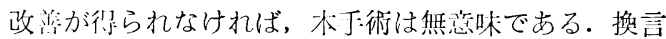
すれば脚长差があるからといつて，よ゙れにもこれにも 下肢延長術は行わるべきものでなく，術前に適応を吟 味して慎重に行うべきものと考えるが，しかしこの適 応決定は䓕だ難しいものの様に思う．以上の我々の僅 かな経験から云えることは，クリッペル・ウェーバー 氏病の如く肥大した患肢を短縮する手術や先天性下腿 偽関领に於ける属肃, 短縮矯正のための下腿延長術は 効果的であるが，反面ポリオに対する下肢延長術は短 縮に加えて筋および神経の障害があるので，余程よい 適応を選ばない限り，労多くして効少ない手術ではあ るまいかという感を深くし，今までに行つた症例の経 過を注涩深く锶察したいと思っている.

質問大宮崎淳弘 脚長差が $6 \mathrm{~cm}$ 位なら凡そ手術の目的を達するとし て良いか。

\section{答泉根整肢学園 花 北 良 臣} 延長術の長さが $6 \mathrm{~cm}$ 程度（即ち短縮が $6 \mathrm{~cm}$ ) なら ばよい適応であるというのではなく，忠側下肢の筋力 の状態に手術成續が左右されるのではあるまいかと思 つている. 